\title{
Comments on R.C. Guimarães' 'The systemic concept of the gene at age fifteen'
}

\section{To the Editor:}

Romeu Guimarães sent to the editor of Genetics and Molecular Biology a letter regarding a paper I published in this journal, entitled "Between the cross and the sword: the crisis of the gene concept" (El-Hani, 2007). First of all, I have to say that it is very pleasant that my paper received attention from a researcher I so deeply respect. I would like to make some comments, here, on arguments offered by Guimarães.

Guimarães was capable of highlighting some aspects of my paper, which may not come to the fore at first, and I am grateful for this contribution to a proper reading of my arguments. I adopt a pragmatist viewpoint about scientific definitions, according to which there is no need of claiming that a concept should be entirely general to be useful, as some reviewers of the gene concept seem to assume (e.g., Fogle, 1990). A gene concept need not be entirely general to serve practical purposes in genetic research, and a diversity of gene concepts may have more explanatory and heuristic power, provided the domain of application of each is well delimited by the scientific community. Both bioinformatics top-down approach and bottom-up experimental procedures that characterized genetic and molecular research for most of the $20^{\text {th }}$ century, interestingly discussed by Guimarães, bring contributions to the identification of genes, from the empirical side, and the construction of gene concepts with a precise enough domain of application, from the theoretical side.

Guimarães also comments on a loose definition mentioned by Pearson (2006), in a recent report published in Nature, according to which a gene could be conceived as $a$ locatable region of genomic sequence, corresponding to a unit of inheritance, which is associated with regulatory regions, transcribed regions and/or other functional sequence regions. The expectation is that this concept might accommodate everyone's demands. Guimarães offers some optimistic remarks on this concept. I should say I am not so optimistic. From my viewpoint, this loose concept has negligible effect, if any, on the current debates about the gene, since it has not much to offer with regard to the clarification of this concept. First of all, it is simply a too loose concept to be of any use. Secondly, one of the main problems faced by the gene concept is precisely the problem of segmentation (Kitcher, 1982), namely, how a chromosome might be segmented into genes, understood as units of structure in the genome, beginning and ending in positions which could be easily ascertained in the DNA molecule. The claim that a gene would be a locatable region of genomic sequence echoes the expectation that this problem could be solved without difficulty. Nevertheless, advances in molecular biology in the last three decades only made it harder to reach a putative solution to this problem. With regard to the problem of the gene, no such easy way out seems to be available, even if it is true that a more pragmatic approach may relax the requirements of establishing entirely correct genomic segments, as Guimarães argues. Here, it is not advisable to ignore the knowledge acquired in theoretical biology and philosophy of biology, which have been discussing the gene concept since the 1980s. Symptomatically, publications from these fields are almost entirely absent from Pearson (2006). If we are to advance in the understanding of what is a gene, this is more likely to happen on the basis of a combination of efforts from different fields that address the issue, both from theoretical and empirical viewpoints.

Finally, I would like to stress that I see much promise in Pardini and Guimarães' (1992) systemic gene concept, as a way of grasping how the structure and dynamics of genes - which are highly contextual in nature - are established by cellular processes involved in the responses to internal and external circumstances.

\section{References}

Charbel Niño El-Hani

El-Hani CN (2007) Between the cross and the sword: the crisis of the gene concept. Genet Mol Biol 30:297-307.

Fogle T (1990) Are genes units of inheritance? Biol Philos 5:349-371.

Kitcher P (1982) Genes. Brit J Philos Sci 33:337-359.

Pardini MIMC and Guimarães RC (1992) A systemic concept of the gene. Genet Mol Biol 15:713-721.

Pearson H (2006) What is a gene? Nature 441:399-401. 